\title{
地震計電磁変換器の検定方法とその精度について
}

\author{
松本英照，高橋道夫
}

\section{Calibration Methods for the Electromagnetic Transducer of the Seismometer and Their Accuracy}

by

\author{
Hideteru Matumoto and Michio Takahashi \\ Meteorological Research Institute, Tokyo
}

(Received August 5, 1976)

\begin{abstract}
Newly devised calibration methods to improve accuracy of calibration are discussed together with the conventional methods. Our special transducers which must undergo hard vibrations and shocks before actual operation were calibrated with these methods. It was confirmed that these transducers can stand up against the presumed vibrations and shocks. The advantage of the MKSA unit system in the calculation of natural frequency, damping constant and sensitivity is shown in the course of the discussion.

These calibration methods are as follows:

(1) Natural frequency.

Two methods, named the phase method and the oscillation method, were devised. The circuit diagram of the phase method is shown in Fig. 2. As can be derived from Eq. (17), when the Lissajous figure shows agreement in phase as between coil output and oscillator output, the frequency of the oscillator fits the natural frequency of the transducer. When the damping constant is less than three, the error is at most one percent. The circuit diagram of the oscillation method is shown in Fig. 4. As shown in Eq. (23), the pendulum oscillates just at its natural frequency when the negative resistance, defined in Eq. (20), satisfies the condition of Eq. (21). Fig. 6 shows the record of free oscillation of the pendulum and the record obtained with the oscillation method. As can be seen from Fig. 6, the two frequencies completely agree with each other. Even if the damping constant is greater than three, the error can be lowered less than one percent.

(2) Damping constant.

There are no difficulties in an accurate measurement of the damping constant, if it is very small or very great, even with the conventional methods described by HAGIWARA (1945). But with transducers with nearly critical damping, there appear some problems that make it difficult to measure damping constant accurately with the conventional methods. For such transducers, the so-called resonance method, the circuit diagram of which is shown in Fig. 2, is available. The damping constant can be calculated from the sharpness of the resonance characteristics. The theoretical characteristics and the calculation method are shown in Fig. 7 drawn upon Eq. (31). Owing to the accurate natural frequency measured with the previous methods, even if the damping is nearly critical, one can measure the damping constant accurately with this method.

(3) Sensitivity.

Sensitivity of a transducer can be measured with various methods. The sensitivities of transducers $A$ and $B$ were measured with the following methods in which newly devised
\end{abstract}


methods are included: damping constant method, condenser method, DC current method, weight method, AC current method, test coil method and vibration table method. The measurement values of sensitivities of transducers A and B are summarized in Table 1. Measurement values are consistent with each other except for the vibration table method. So far, without reasonable foundation, some of these methods have been regarded as not so accurate. Nevertheless Table 1 shows that every one of them except the vibration table method is available for accurate measurement of sensitivity.

\section{1. はじめに}

地震現象に対する理解を深めるのには地震動を 正確に観測することがその第一歩である。測定機 器を用いた定量的観測が始められて約 1 世紀の歴 史があるが，この間，測定機器も純機械式から光 学式, 電磁式乞して電子式へと変遷している。そ 机対応して変換器の基本定数, すなわち固有振 動数, 減衰定数扔よび電圧感度の検定に执いても, 長さ・質量・時間の単位のみで足りる測定から電 流の単位を用いる必要のある測定がつけ加わって いる。この報告の目的のひとつは定数を計算する ときに必要な機械量と電気量との間の煩雑な関係 を明瞭にすることにある。このことは MKSA 単 位系索忠実に，例党ば電圧感度の単位に通常用い られている $\mathrm{V} \cdot \mathrm{sec} / \mathrm{cm}$ でなく $\mathrm{V} \cdot \mathrm{sec} / \mathrm{m}$ 用い ることによって成功している[狐崎 (1970)]。こ の研究は筆者らを含吉数人が担当しているケーブ ル式の「海底地震常時観測システムの開発・研究」 に扎いて必要があってすすめられたるのである が，この報告の大きな目的は従来からのもの《比 べて精度のよい検定方法を導入乙変換器の検定確 度の向上に資することにある。

上のシステムについては別に詳しく述べる機会 があると考えられるが，システム開発におけるこ の研究の位置づけを明らかにするためにこのシ ステムに使用する変換器に課せられた条件につい

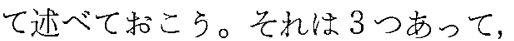

条件(1) 小型で可能な限り長周期であること。

これは $4000 \mathrm{~m}$ の深海にお竹る水圧に耐える容 器内に収納しなければならないので耐圧容器の 内容積の制限と, 地震計としての望ましい周波 数特性とによる。

条件(2) 高耐振動・衝撃性を有すること。

これは海底化設置する際の布設工法上，布設船 上で大きな振動・衝撃を受けることがさげられ ないことによる。
条件(3) 経年的安定した特性を有すること。 これは海底に設置されたのちは修理は勿論, 調 整も検定も不可能であり，10 年以上の長きにわ たって安定に作動しなければならないことによ る。

変換器はこのような条件を課せられているの で，実際に予測される大きさの振動・衝撃を与兄 る試験や枯化試験も実施しなければならない。そ れらの試験の之き，損傷や不安定性に起因寸る基 本定数のわずかな変化をとら兄るためには，従来 の湘定方法の精度では，充分でないことが開発初 期に発見された。このために基本定数の正確な検 定方法を砗立して和くことが不可欠であり，従っ てこの報告の大部分はこれらの基本定数の測定に ついて方の方法, 精度扐よび実際に得られた結果 と留意しなければならない点について述べる。

一般に地震計に打いて変換器出力が地震記象之 なるまでに諸種の電子回路を通過するが，これら の電子回路の特性の測定は計測器の完備してきた 現在，容易にから正確に測りらる。それゆえ地震 計の総合特性を論じる際, 変換器の基本定数測定 の不正確さが大きく影響する。例觉ば固有振動数 扣よび減衰定数の不正確さはスペクトルを比べ るとき，特に固有振動数前後の周波数に和活る ペクトルの大きさの不正確さ淔接ひびくし，電 压感度の不正確さは異なる交換器の間の情報の互 換性を失うことになる。総合特性を一挙に求める 方法に比較し, 変換器の特性と電子回路の特性と から総合特性を求める方法が原理的にもより正確 であるはずだから，そのためにも変換器の基本定 数を正確につかんで就くことが欠くことのできな い手続きであると考光られる。

本論に扣いて快各種の検定法がとりあげられる のでそれらの方法の位置づけについてふれて拈く ことにする。固有振動数を測る 3.1 の位相法はそ れ自体新しい考方方ではないが，電磁変換器に応 用してその精度が 確められたのは初めてである。 
3.2 の発振法は質的に 新しい方法である。減衰定 数を測る 4.1 の共振法は固有振動数をあらかじめ 求めて打いてこの方法を適用するところに新しさ がある。また電圧感度がわかっている場合には外 ら゙けのダンパーに上る減衰定数までも発振法を用 いて同時に計算できる点で測定法としての前進が ある。電生感度を測る 5.1 の減衰定数法, 5.2 の 容量法は今まで見られなかったものである。また 5.5 の交流電流法, 5.6 のテストコイル法には新 しい工夫がもりこまれている。 5.3 の直流電流法 は古くから気象庁でルーチン的に用いられていた 方法である。5.4 の重錘法は最も信頼が物けると 考えられて，ひろく用いられていた方法である。 5.7 の振動台法性手軽であるから一般的に広く重 宝されていた方法である。

\section{2. 基本関係式}

この節では基本定数の測定を理解するらえに必 要な, 振子の軍動方程式および コイルの発電の式 をとりあげ，それらと固有振動数・減衰定数・電 圧感度の関連について述べる。

変換器振子の運動方程式は理想的な場合, 次の ように書ける。ただし変換器にはメインコイルと テストコイルの両方がついているものとする。

$$
K \ddot{\theta}+D \dot{\theta}+U \theta=-M H \ddot{x}-G_{1} I_{1}-G_{2} I_{2}
$$

またコイルの雨端に生じる起電力は,

$$
\begin{aligned}
& E_{S_{1}}=G_{1} \dot{\theta} \\
& E_{S_{2}}=G_{2} \dot{\theta}
\end{aligned}
$$

(1)〜(3) に执いて（かつこ内は MKSA 系によ る単位),

$K:$ 振子の回転軸まわりの慣性モーメント $\left(\mathrm{kg} \cdot \mathrm{m}^{2}\right)$,

$D:$ 振子の単位角速度あたりの制動力のモーメ ント $\left(\mathrm{kg} \cdot \mathrm{m}^{2} / \mathrm{sec}\right)$,

$U$ : 振子の単位角変位あたりの復元力のモーメ ント $\left(\mathrm{kg} \cdot \mathrm{m}^{2} / \mathrm{sec}^{2}\right)$,

$\theta:$ 振子のられの角度 (rad.),

$M:$ 振子の質量 $(\mathrm{kg})$,

$H$ : 振子の重心から回転軸をでの距離 $(\mathrm{m})$;

$x:$ 地動変位の受感方向成分 $(\mathrm{m})$,

$G:$ 動電定数 $(\mathrm{V} \cdot \mathrm{sec})$,

$I:$ コイルに流れる電流 $(\mathrm{A})$,

$E_{S}:$ コイルに誘起される起電力 $(\mathrm{V})$ 。
また，

添字 1: メインコイルに関する量, 添字 2: テストコイルに関する量。 な招動電定数 G は理想的な場合には,

$$
G=2 \pi a N B L
$$

ここで,

$a:$ コイルの半径 $(\mathrm{m})$,

$N:$ コイルの巻数,

$B$ : 磁場の磁束密度 $\left(\mathrm{Wb} / \mathrm{m}^{2}\right)$,

$L:$ :イルの中心と回転軸との距離 $(\mathrm{m})$ 。

(1) （4）に叔いて各種の機械量・電気量の単位 に，かっこ内に示した MKSA 系以外のものを用 いれば式中の相当する項汇 変換の定数を係数とし てつけ加えなければならない。MKSA 系だとこ のように簡便なので以下ではすべての単位に MKSA 系を用いる。

固有振動数 $f_{0}$, あるいは固有角振動数 $\omega_{0}$ は衆 知のように,

$$
\omega_{0}=2 \pi f_{0}=\sqrt{\frac{U}{K}}
$$

減衰定数 $h$ は，図 1 に示すようにメインコイ ルの抵抗を $R_{C 1}$, それに外づけされた抵抗を $R_{D 1}$, テストコイルのそれらを $R_{C 2}, R_{D_{2}}$ としたとき (1)〜(3) からわかるように，

$$
h=\frac{1}{2 \omega_{0} K}\left[D+\frac{G_{1}{ }^{2}}{R_{C 1}+R_{D 2}}+\frac{G_{2}{ }^{2}}{R_{C 2}+\overline{R_{D 2}}}\right]
$$

となる。(6)は,

$$
h=h_{0}+h_{e}
$$

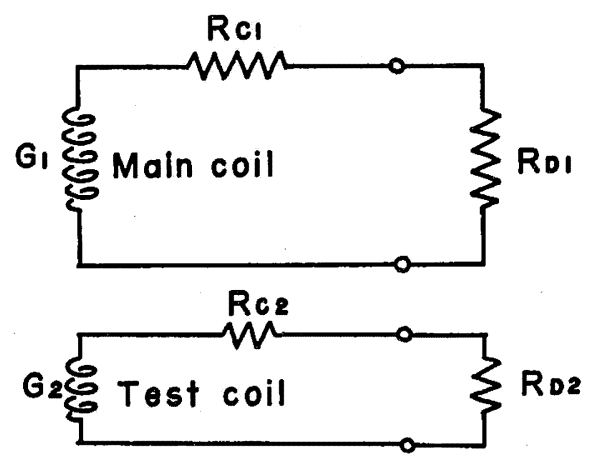

Fig. 1. Schematic diagram showing connections of termination resistances $R_{D 1}$ and $R_{\mathrm{D} 2}$ to the output coil and the test coil of the transducer respectively. $R_{C_{1}}$ and $R_{C_{2}}$ represent the internal resistance of both coils. 
ここで,

$$
\begin{gathered}
h_{0}=\frac{D}{2 \omega_{0} K} \\
h_{e}=\frac{1}{2 \omega_{0} K}\left[\frac{G_{1}{ }^{2}}{R_{C 1}+R_{D 1}}+\frac{G_{2}{ }^{2}}{R_{C 2}+R_{D 2}}\right]
\end{gathered}
$$

のように分割して考えられることもある。 $h_{0}$ は両 コイルを開放したときの減衰定数で, 空気の流体 抵抗のみのときはその值は小さいが，オイルダン パーや電磁ダンパーが付加されているときは大き くなる。 $h_{e}$ はコイルに電流が流れることによる減 衰定数で，(7) は最終的な振子の減衰定数は両者 の和であることを示している。

電圧感度 $S_{v}$ は,

$$
S_{v}=\frac{G}{l}
$$

ここで,

$$
l=-\frac{K}{M H}
$$

で与えられる。l は長さの次元をもつ量で，振子 を回転軸のをわりに回転する剛体とみなしたとき の相当単振子長である。

以上は振子が軸のまわりに回転する型の変換器 の場合であるが，振子が直線運動をするいわゆる 直動型振子の場合はもっと簡単で $(1) \sim(10)$ に相 当する式は次のようになる。

$$
\begin{aligned}
& M \ddot{y}+D^{\prime} \dot{y}+U^{\prime} y=-M \ddot{x}-G_{1}{ }^{\prime} I_{1}-G_{2}{ }^{\prime} I_{2} \\
& E_{S_{1}}=G_{1}{ }^{\prime} \dot{y} \\
& E_{S_{2}}=G_{2}{ }^{\prime} \dot{y} \\
& G^{\prime}=2 \pi a N B \\
& \omega_{0}=2 \pi f_{0}=\sqrt{\frac{U^{\prime}}{\bar{M}}} \\
& h=\frac{1}{2 \omega_{0} M}\left[D^{\prime}+\frac{G_{1}^{\prime 2}}{R_{C 1}+R_{D 1}}+\frac{G_{2}{ }^{\prime 2}}{R_{C 2}+R_{D 2}}\right] \\
& h=h_{0}+h_{e} \\
& h_{0}=-\frac{D^{\prime}}{2 \omega_{0} M} \\
& h_{e}=\frac{1}{2 \omega_{0} M}\left[\frac{G_{1}{ }^{2}}{R_{C 1}+R_{D 1}}+\frac{G_{2}{ }^{2}}{R_{C 2}+R_{D 2}}\right] \\
& S_{v}=G^{\prime}
\end{aligned}
$$

量であるが次元が異なり，

$$
\begin{aligned}
& D^{\prime}: \mathrm{kg} / \mathrm{sec} \\
& U^{\prime}: \mathrm{kg} / \mathrm{sec}^{2} \\
& G^{\prime}: \mathrm{V} \cdot \mathrm{sec} / \mathrm{m}
\end{aligned}
$$

な拈 $l$ に相当する量は直動型の場合には存在しな い。直動型の場合もほぼ同様の議論となるので以 下に拈いてはとりあげない。

減衰定数拈よび電圧感度の測定においては固有 振動数の正確な值が必要な場合が多い。をた減衰 定数を測定して電圧感度を求めるという方法もあ る。このため固有振動数, 減衰定数, 電圧感度の 順にその測定について述べる。

\section{3. 固有振動数の測定}

減衰定数が 1 より充分小さい状態にある恋換器 振子の固有振動数は自由振動させて測定する方法 を用いても何ら問題なく正確に測定できる。しか し, 海底地震常時観測システムには次に述ベる理 由でュイルの両端を開放しても約 1 の大きさの減 衰が残る变換器が使用されるために自由振動が不 可能で，固有振動数は簡単には測れない。その理 由は, このシステムに使用する変換器は耐振動・ 衝撃特性が良いことが必要であるだけでなく，小 型といら絶対条件を課せられているので変換器製 作に括いて採用された方針は，固有振動数はやむ を得ず大きくとるが，低周波域を電子回路で等化 するというものであった。この方針に基いて検討 した結果，振子の減衰定数は大きくとった方が電 子回路の素子の数が少なくなり回路設計が容易に なることが明らかとなった。大きな減衰定数を得 るためには，外ら゙け抵抗を小さくするよりもなん らかのダンパーを用意する方が回路の $S / N$ 設計 に有利なことは当然である。このためコイル枠に 非鉄金属を使用し電磁 ダンパーとして働かせた。 以上の理由でこの変換器にははじめから減衰定数 が約 1 の制動作用があるので自由振動をしない。 一般に, このような大きな制動をるつ変換器の固 有振動数扣よび減衰定数を測定するには困難がと もない, 臨界減衰に近い状態にある変換器の検定 に関する工藤ら (1968) の研究もあるが，これも 耐振動・衝撃試験による 微小な変化をとらえると いう目的にはその精度が充分ではない。このよう な背景のもとに開発した後述の検定方法により, 実際に振動・衝撃試験を実施しそれによって固 
有振動数がわずかではあるが有意義に変化するか ぞうかを調べ，耐振動・衝撃性能の評価が可能に なったことが確められた。また海底に設置する前 に短期間の枯化による変化を調べ，それから海底 設置後の長期間の変化を推定するのにも充分に役 立つ方法であると考㝋ている。

コイルの両端を開放しても大きな減衰が残る, すなわち（8）の， $h_{0}$ が小さくないという事情はこ の場合の電磁ダンパーのみならず, 空気ダンパー, オイルダンパーなどの場合にもあてはまることで ある。次に述べる2つの方法恃これらの場合にも 㐫用できる。

\section{1 位相法}

変換器を静止した台にのせて, 眓 2 のよらにテ ストコイルに発振器から交流電流を流すとしよ ら。このときコイルに流れる電流は（2)，(3) よ り,

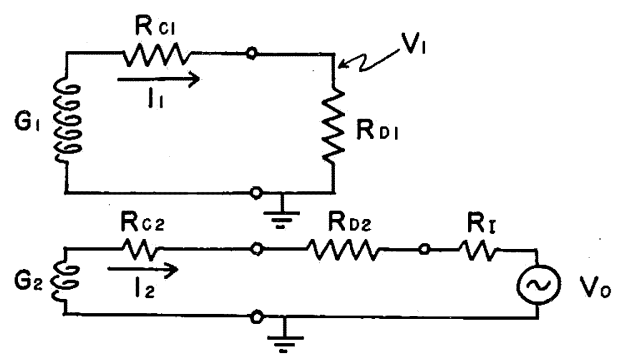

Fig. 2. Circuit diagram common to the phase method, the resonance method and the test coil method.

$$
\begin{aligned}
& I_{1}=\frac{G_{1} \dot{\theta}}{R_{C 1}+\overline{R_{D 1}}} \\
& I_{2}=\frac{G_{2} \dot{\theta}-V_{0}}{R_{C 2}+R_{D 2}+R_{I}}
\end{aligned}
$$

よって振子の運動方程式 (1) は,

$$
\begin{aligned}
& K \ddot{\theta}+\left(D+\frac{G_{1}{ }^{2}}{R_{C 1}+R_{D 1}}+\frac{G_{2}{ }^{2}}{R_{C 2}+R_{D 2}+R_{I}}\right) \dot{\theta} \\
& \quad+U \theta=\frac{G_{2} V_{0}}{R_{C 2}+R_{D 2}+R_{I}}
\end{aligned}
$$

または，次のようにも書き替えられる。

$$
\begin{gathered}
\quad \ddot{\theta}+2 h \omega_{0} \dot{\theta}+\omega_{0}{ }^{2} \theta=G_{2} K^{-} V_{0} \\
\text { ここで, } \\
h=\frac{1}{2 \omega_{0} K}\left(D+\frac{G_{1}{ }^{2}}{R_{C 1}+R_{D 1}}+\frac{G_{2}{ }^{2}}{R_{C 2}+R_{D 2}+R_{I}}\right)
\end{gathered}
$$

$$
R=R_{C 2}+R_{D 2}+R_{I}
$$

また， $R_{D 1}$ の両端の電位差 $V_{1}$ は（12）を用いて

$$
V_{1}=\frac{R_{D 1}}{R_{C 1}+R_{D 1}} G_{1} \dot{\theta}
$$

$\dot{\theta}$ と $V_{0}$ の位相の差 $\delta$ はよく知られているよう に(15)より

$$
\begin{gathered}
\text { ここで, } \quad \begin{array}{c}
\delta=\tan ^{-1}-\frac{1-u^{2}}{2 h u} \\
u=\frac{\omega}{\omega_{0}}
\end{array}
\end{gathered}
$$

(16) に示されるよらに $\dot{\theta}$ と $V_{1}$ には位相差はな いので (17) に示される $\dot{\theta}$ と $V_{0}$ の位相差がその まま $V_{0}$ と $V_{1}$ の位相差に执きかえられる。(17) よりわかるように $\delta=0$ となる $\left(V_{0} と V_{1}\right.$ の位相 が一致する)のは $u=1$ すなわち発振器の周波数と 振子の固有振動数とが一致したときのみである。 位相の一致点を検出する方法としては，コイルの 出力と発振器出力をシンクロスコープにつなぎ, そのブラウン管上でリサジュ一図を描かしながら 発振器の周波数を調整し, 長円がつぶれて完全に 一本の線になる周波数をさがせばよい。そのとき の周波数をカウンターで読みとると，それが固有 振動数である。実験的に確認したところによる と, リサジュ一図により 2 つ信号の位相が一致 したことを検出する精度として0.2度を得ることは 容易である。したがって（17）からわかるように 減衰定数が 3 以下の場合には固有振動数は $1 \%$ 以 上の精度で測定できる。測定に際しては, 減衰が 小さい汪ど精度がよいので図 2 の回路に执いて $R_{D}$ は大きい核ど好ましい。またコイルはとの形 からもわかるように $R_{C}$ 之直列に自己インダクタ ンスを，両コイル間に相互インダクタンスを伴う が，これ怟周波域では問題にならないし，そう でなくても $R_{D}$ 大きくとることにより無視するこ とができ，実際に減衰定数が 3 以下の場合には 1\%の精度が得られていることを確かめた。

\section{2 発振法}

变換器は受動的電気力学変換器であるから等価 回路（定電流表示）を考光ることができる（図 3) 〔田（1963）など】。この等価回路表示に沶いて地 動加速度 $\ddot{x}$ は左側の両端子から流れこさ電流

$$
I_{0}=-\frac{M H}{G} \ddot{x}
$$




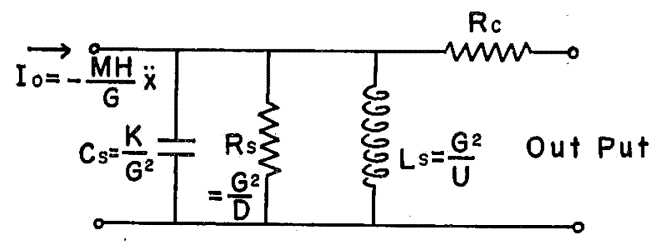

Fig. 3. Equivalent circuit of a transducer.

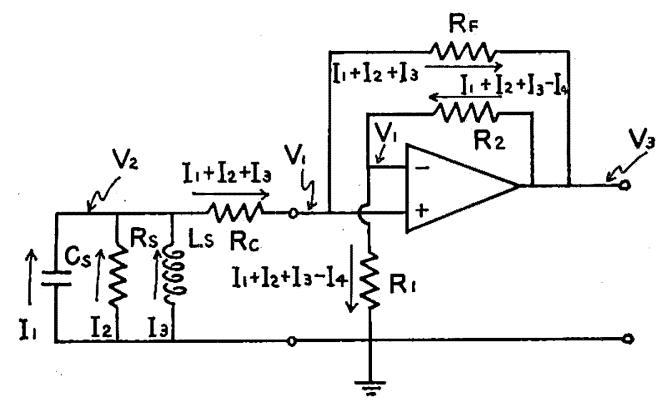

Fig. 4. Circuit diagram of the oscillation method.

に相当する。またコイルの出力端子が右側の両端 子に相当する。 $C_{S}, L_{S}, R_{S}$ の值は図に書かれて いる各値に相当するので，

$$
\omega_{0}=\sqrt{\frac{1}{L_{S} C_{S}}}
$$

（18）に示されるように固有振動数を求めることは 図 3 に打忷る $L_{S} C_{S}$ を求めることに相当する。它 の方法として例觉ば図 4 のように演算増幅器を用 いて負性抵抗回路を構成し， $R_{1}, R_{2}, R_{F}$ を調節 すれば回路 (变換器) は発振を始める。 $V_{3}$ が正し い正弦波で発振しているときの周波数が固有振動 数になっているのでそれをカウンターを利用して 読みとる。

演算増幅器を理想的なものとして，各部を流れ る電流，電位を図40ように与えたとき，キルヒ ホッフの法則より，

$$
\begin{aligned}
& -V_{2}=\frac{I_{1}}{j \omega C_{S}}=R_{S} I_{2}=j \omega L_{S} I_{3} \\
& V_{2}-V_{1}=R_{C}\left(I_{1}+I_{2}+I_{3}\right) \\
& V_{1}-V_{3}=R_{F}\left(I_{1}+I_{2}+I_{3}\right) \\
& V_{3}-V_{1}=R_{2}\left(I_{1}+I_{2}+I_{3}-I_{4}\right) \\
& V_{1}=R_{1}\left(I_{1}+I_{2}+I_{3}-I_{4}\right)
\end{aligned}
$$

これらより，

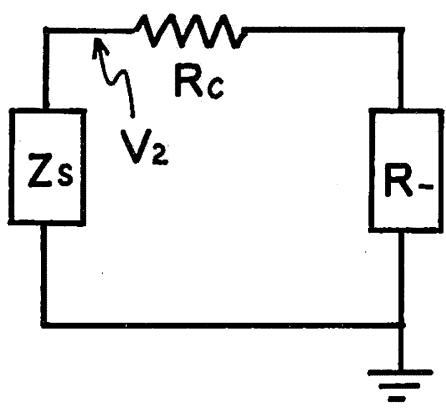

Fig. 5. Equivalent circuit of Fig. 4.

$$
\frac{V_{1}}{I_{1}+I_{2}+I_{3}}=-\frac{R_{1}}{R_{2}} R_{F}
$$

従ってここで,

$$
R_{-}=-\frac{R_{1}}{R_{2}} R_{F}
$$

$$
-\frac{1}{Z_{S}}=j \omega C_{S}+\frac{1}{R_{S}}+\frac{1}{j \omega L_{S}}
$$

と打くと図4 は図 5 のように簡単になり,

$$
\frac{V_{2}}{Z_{S}}+\frac{V_{2}}{R_{C}+R_{-}}=0
$$

または，

$$
Z_{S}+R_{C}+R_{-}=0
$$

（21）は発振条件を与光るものでその実数部の関係 から電力条件

$$
R_{S}+R_{C}+R_{-}=0
$$

虚数部の関係から周波数条件

$$
\omega=\sqrt{\frac{1}{L_{S} C_{S}}}=\omega_{0}
$$

を得る。(23) は発振周波数が振子の固有振動数に なっていることを示す。(22) については減衰定数 の測定の節でふれる。

演算增幅器に位相のおくれがあると発振周波数 は固有振動数からずれてくるが，これは一般に充 分小さいものであり，振子の減衰定数が 3 よりも 大きいときでも $1 \%$ の精度が得られることが確か められた。

図 6 は, ある変換器について自由振動させた記 録と，外づけ抵抗を小さくすることによって減衰 定数を 5 にしたのち発振させた記録とを示す。振 動数はよく一致している。また位相法による測定 結果もこれらと一致した。 

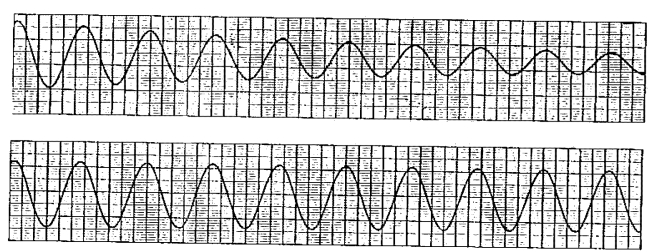

Fig. 6. Two records obtained from the same transducer. The upper one is the record of free oscillation when $\mathrm{h} \fallingdotseq 0$. The lower one is the record obtained with the oscillation method when $\mathrm{h} \fallingdotseq 5$.

一般に固有振動数の測定に抢いて振子のふれ幅 を実用的な振幅以上に大きくするとバネ等の復元 力の非線型性が無視できなくなり，誤まった結果 を得ることがあるので注意しなりればならない。 いいか觉ると，(1) K拈沙る復元力項 $U \theta$ は実は $U \theta+U^{\prime} \theta^{2}+U^{\prime \prime} \theta^{3}+\cdots$ というのを， $\theta$ が小さい ために第 2 項以下を省略した形であるから， $\theta$ が 小さいらちは充分によい近似であったものが， $\theta$ が大きくなると無視できなくなることに相当す る。しかし振子のふれ幅が小ささざると地動雑微 動に邪魔されることもあるので，測定にあたって は変換器の構造, 特に大きさを考元て最適のふれ 幅に抽いて行わなければならない。この事情はど のような方法を用いても生じてくる問題である。

\section{4. 減衰定数の測定}

先に述ベたシステムに揖いて，低周波域を等化 するための電子回路の周波数特性を設計するにあ たり，固有振動数のみならず減衰定数の值が必要 となる。減衰定数は $(7) \sim(9)$ に定義されている が，そのらちの $h_{e}$ については（9）からわかるよ らに動電定数等を測定することによって算出でき る。(8)の $h_{0}$ については $D$ の測定が至難である からむしろ $h_{0}$ を直接測定した方がよさそうに思 われる。しかし発振法で得られた発振の電力条件 （22）から，図 3 の等価回路表示に打忙る

$$
R_{S}=\frac{G^{2}}{D}
$$

の関係，扣よび (8) から，

$$
h_{0}=\frac{G^{2}}{2 \omega_{0} K} \frac{1}{\frac{R_{1}}{R_{2}} R_{F}-R_{C}}
$$

すなわち $h_{0}$ についても動電定数等から, 発振法 を用いて，算出することができる。従って減衰定 数の測定と動電定数（または電代感度）の測定と は互いに他にとってかわりらるものであるといえ る。

それはそれとして動電定数を知らないで減衰定 数を測定することを考えよう。一般に減衰が充分 に小さいときは自由振動の記録の減衰比から算出 寸る方法で充分な精度がえられる。この場合, 固 有振動数の值をあらかじめ知って叔く必要はない ので測定は簡単である。また減衰が充分に大きい ときは記録の過減衰曲線からその対数の時間変化 率を測定し算出することができる〔萩原（1945） など】。この場合は固有振動数の值をあらかじめ 知って沶く必要があり, そのためには前述の方法 が有効である。減衰が臨界制動前後の大きさの ときは，そのいずれの方法も精度が低くなる。す なわち減衰定数が 1 より少しだけ小さいとさは記 録から読みとる減衰比の誤差が大きくなる。もし くは記録器のダイナミックレンジの制限から減衰 比が読みとれなくなる。例觉ば減衰定数が 0.7 の

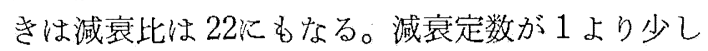
だけ大きいときも次のような事情で過減衰曲線の 対数の時間変化率を測定することが困難になる。 その事情とは，振子にある初期変位と初期速度と を与えて自由にしたとき，得られる記録はよく知 られているよらに白に比例し，

$$
\begin{aligned}
& \dot{\theta}=A e^{\left(-h+\sqrt{\left.h^{2}-1\right)} \omega_{0} t\right.}+B e^{(-h-\sqrt{h-1}) \omega_{0} t} \\
& \text { ここで, }
\end{aligned}
$$$$
A, B \text { ：与える初期条件により決る定数。 }
$$

減衰定数が 1 より充分大きければたとえ $B$ の絶 対值が $A$ 上り相当大きい初期条件を与交ても(26) の第2項は時間とともにすみやかに減衰し第1項の みが残る。そのような時間が経たのちの記録から 減衰定数が正確に計算できる。ところが減衰定数 が 1 に近い值の場合には(26)の第 2 項が必ずしも すみやかに減衰しない。したがってある一定の長 い時間を経た後の記録を読みとらなければならな くなる。ぬた与光る初期条件を厳密に一定に保つ ことが困難なときには（26）の $B$ が大きくなる 初期条件を与えてしまうこともあるだろう。この 場合に法 $B$ が大きくても第 2 項が 無視できるよ らに更に長い時間を経た後の記録を読みとらなけ ればならない。この時, 記録の振幅はすでに小さ 
くなっていて地動雑音の混入がさけられず結果の 再現性も悪くなる。地動雑音という観点からすれ ば減衰定数のあまりにも大きいものも測定が困難 である。

先に述べた工藤ら（1968）の臨界減衰に近い状 態にある振子の固有振動数と減衰定数とをインパ ルス応答から同時に求めようとする試みもある が，筆者らは固有振動数は正確に測定できるとい ら前提に立ち，電気信号により振子に強制振動を 与えて共振させてより正確に減衰定数を測る方法 について述べる。

\section{1 共振法}

回路は図 2 と同様に構成する。ただし， $R_{D_{1}}$ と $R_{D 2}$ とは充分大きくとってあるにもかかわらず, 振子は減衰定数にして, 約 1 の減哀の状態にある ものとする。このとき振子の運動方程式 (1) は (15) と同様に,

$$
\ddot{\theta}+2 h \omega_{0} \dot{\theta}+\omega_{0}^{2} \theta=\frac{G_{2}}{K R}-V_{0}
$$

ここでこの場合は,

$$
h=h_{0}
$$

メインコイルの出力 $V_{1}$ は $(16)$ で $R_{D 1} \rightarrow \infty$ とし $\tau$,

$$
V_{1}=G_{1} \dot{\theta}
$$

さらに(27) を用いて

$$
V_{1}=-\frac{G_{1} G_{2}}{K R}-\frac{V_{0}}{j \omega+2 h \omega_{0}+\frac{\omega_{0}^{2}}{j \omega}}
$$

$V_{0}$ の振幅 $\left|V_{0}\right|$ を一定にして 周波数を变化させ て $V_{1}$ の振幅 $\left|V_{1}\right|$ 飞注目すると

$$
\begin{aligned}
\quad\left|V_{1}\right|=C \cdot \frac{u}{\sqrt{\left(1-u^{2}\right)^{2}} \overline{(2 h u)^{2}}} \\
\text { ここで } \\
u=\frac{\omega}{\omega_{0}} \\
C=\frac{G_{1} G_{2}-\left|V_{0}\right|}{K R}
\end{aligned}
$$

$\left|V_{1}\right|$ の值は（30）からわかるように

$$
\begin{aligned}
& u \gg 1 \text { のとき }\left|V_{1}\right|=C \cdot \frac{1}{u} \\
& u=1 \text { のとき }\left|V_{1}\right|=C \cdot-\frac{1}{2 h} \\
& u \ll 1 \text { のとき }\left|V_{1}\right|=C \cdot u
\end{aligned}
$$

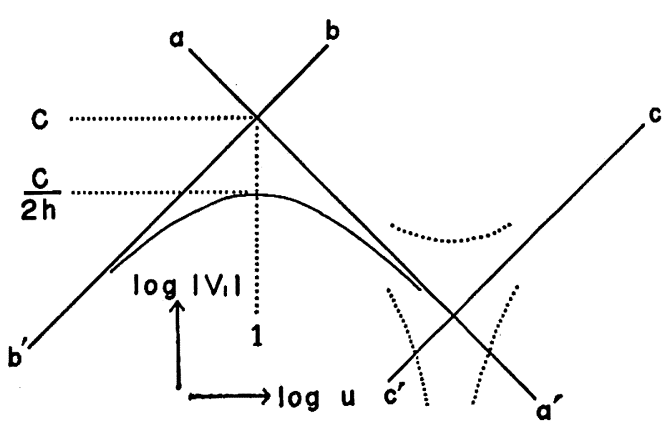

Fig. 7. Theoretical output of the resonance method. The damping constant h can be calculated from the relation between the measurement value $\mathrm{C} / 2 \mathrm{~h}$ at the natural frequency and the cross point value $C$ of $a-a^{\prime}$ and $b-b$ '.

(30)，(31）からわかることは図7 のように横軸に $\log u$, たて軸に $\log \left|V_{1}\right|$ をとったときグラフは $u=1$ の左右で対称で, $u=1$ の之き $\left|V_{1}\right|=C / 2 h$ の值をとる。uが 1 より大きくなるに従って $\left|V_{1}\right|$ は直線 $\mathrm{a}-\mathrm{a}^{\prime}$ に溸近し， $u$ が 1 より小さくなるに 従って b- $b^{\prime}$ に潮近する。a-a' れ $-6 \mathrm{~dB} /$ oct., $+6 \mathrm{~dB} /$ oct. の勾配で $u=1,\left|V_{1}\right|$ $=C$ で交わる。 $\omega_{0}$ 样前節の方法で正確に求めて 扣き, 数点の $u\left(=\omega / \omega_{0}\right)$ に和いて $\left|V_{1}\right|$ を測定 しグラフ上にプロットすることにより $\mathrm{a}-\mathrm{a}^{\prime}, \mathrm{b}-\mathrm{b}^{\prime}$ をひく。 $u=1$ に和ける $\left|V_{1}\right|$ の測定值 $C / 2 h$ と $\mathrm{a}-\mathrm{a}^{\prime}$ と $\mathrm{b}-\mathrm{b}^{\prime}$ との交点の $\left|V_{1}\right|$ の值 $C$ とから減 衰定数が算出できる。

$\mathrm{a}-\mathrm{a}^{\prime}$ を決めるとき注意しなければならないのは 周波数が大きくなったときにあらわれる両コイル 間の相互インダクタンスの効果で, こ机は図 7 に 拈いて c-c'圤らにあらわ机てくるしたがって $\left|V_{1}\right|$ は高周波になると $\mathrm{a}-\mathrm{a}^{\prime}$ からずれて，相互イ ンダクタンスが同相であるか逆相であるかによっ て、 a-a' と c-c'との和または差となる。このた め相互インダクタンスの大きい変換器は $\mathrm{a}-\mathrm{a}^{\prime}$ を 決めるのが困難となる。

この共振法で虻，あらかじめ固有振動数を知っ ていなくてもよさそうに思われるが，より精度の 高い測定を行抢うとすればその值子不可欠のもの である。といらのは臨界減衰に近い状態では共振 は全く鋭くなく，最大振幅をさがすことによって 固有振動数を決めようとすると通常の場合士15\% 程度の誤差が入ってくるのはさけられず,その誤差 
が直接に減衰定数にきいてくる。また一般に行わ れているように $\mathrm{a}-\mathrm{a}^{\prime}$ と $\mathrm{b}-\mathrm{b}^{\prime}$ の交点の周波数を 固有振動数とする方法も，先にのべた相互インダ クタンスの効果で $\mathrm{a}-\mathrm{a}^{\prime}$ が決り難く，また地動雑 音の大きい場所では特に，精度が低いことを筆者 らは確めてある。共振法に扣いては固有振動数の 正確な值を知って和くことが必要である。

正確な固有振動数の值が得られていると，この ように減哀定数まで正確に測れる効果を述べた が，次にのべる電圧感度の測定においても正確な 固有振動数の值を使用する必要のある方法が多 い。このあたりの事情にも固有振動数の測定精度 をあげる必要があらわれている。

\section{5. 電圧感度の測定}

電圧感度は記象の振幅から地動の大きさを算出 するために重要な基本定数であるが，その精度は 10パーセントで充分であるといらのが従来の， あ るいは現在の一部の人達の考え方である。これれは 主として, 地動振幅の大きさは変換器の扣かれて いる場所の地盤によって数十パーセントも変動す るといら難点があり，そらいら背景から記象から 得られる振幅の情報は周波数の情報や初動方向の 情報に比べて理論地震学上, 比重が大きくなかっ た，という理由によるものである。しかし将来に 扣いて，例えば振幅に和ける理論地震学上の大き な発展があって 正確な感度を必要とする時がくる かもしれない。われわれのシステムについて考兄 ると, 一度海底に設置したが最後, 修理・調整・ 検定は不可能であるから設置前により 正確な值を 知りかつそれが経年的にどのよらに変化するかを 知って持きたいのである。

電圧感度の測定は固有振動数や減衰定数とちが って実にいろいろな方法が考えられる。しかしあ る特定の変換器についてそれらのすべての方法を 用いることは主として構造上の問題から不可能な こともある。それは例えば振子が目に見えないよ らな構造のときである。本節ではいろいろの新し い方法を含む測定方法を紹介し，その結果がょく 一致すること, 従って変換器個々の事情により測 定方法が異ったとしても得られた值の間には互換 性があるという，いわば当然のことであるが，従 来は一元的にしか測定をしえなかったために 確認 が得られていなかった計測上の確度について述べ

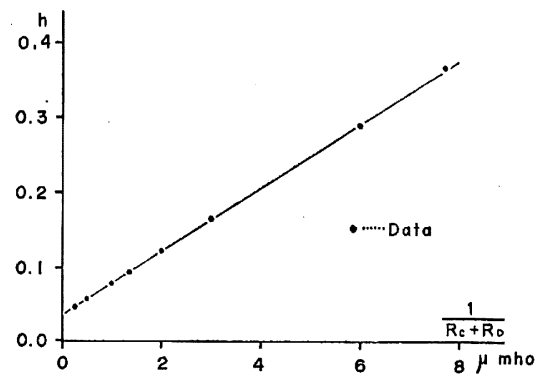

Fig. 8. Relation between $1 /\left(R_{C}+R_{D}\right)$ and $h$ when the damping constant method was applied to transducer A.

る。

\section{1 減衰定数法}

減衰定数は動電定数と (7) (9) の関係にある。 ある $R_{D}$ を与えて自由振動させてその記録から減 衰定数を求めることを二通り以上行えば動電定数 が決り，事前に相当単振子長がわかっていれば電 圧感度が得られる。ある変換器 $A$ について実験 した結果を図 8 に示す。最小二乗法で決めた直線 の勾配からあらかじめ测定してある $\omega_{0}, K, l$ 等 の值を用いて電圧感度を計算し $445 \mathrm{~V} \cdot \mathrm{sec} / \mathrm{m}$ を 得た。

\section{2 容量法}

コイル出力に並列に容量 $C[$ farad $]$ をつなぐと (図 9 ), 振子の固有振動数は $f_{0}$ から $f_{0}^{\prime}$ に変化 する [BENIOFF (1960) など],

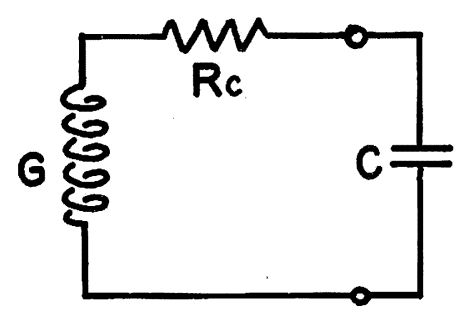

Fig. 9. Circuit diagram of the condenser method.

$$
{ }^{-f_{0}{ }^{\prime}}{ }^{\prime}=\sqrt{1+{ }^{-}} C G^{2-}
$$

このことは図 3 の等価回路表示からもらかがえ る。（32）の関係を用いて動電定数がわかるので電 圧感度を得る。この方法は固有振動数を有意に変 化させるために，一般に大容量のケミカルコンデ ンサーを必要とする。その大容量值を正確に知る 
ためには複雑な手続きを要するが，決して困難で はない。変換器 $A$ についてこの方法で電圧感度 を測定したところ 3 と扣りの容量に対してそれ ぞれ，453，451，464 V·sec/m を得た。

\section{3 直流電流法}

コイルに直流電流を流すとき（1）は大部分の項 が消壳，

$$
\begin{array}{ll}
こ こ て ゙, & U \theta=-G I \\
& U=K \omega_{0}{ }^{2}
\end{array}
$$

$\theta$ の測定には顕微鏡を用いる。(33) から動電定数 が，従って電圧感度が得られる。電流を大きくす ると振子のふれの角が大きくなって復元力の非線 型項が無視できなくなるだけでなく，コイルを横 切る平均の磁界も弱くなり 動電定数そのものも小 さく見えてくることがあるといら 2 点に留意して 測定しなければならない。振子のふれの角は実用 振幅内に収めるべきである。変換器 $A$ は上下動 にも水平動にも使用できる型のものであるが，そ れを上下動として使用し，実験の結果 $I$ と $\theta$ と の関係として図 10が得られた。これから算出され た上下動として使用したときの電圧感度は 444 $\mathrm{V} \cdot \mathrm{sec} / \mathrm{m}$ である。同一変換器を同一条件で水平 動として使用し，同様にして $445 \mathrm{~V} \cdot \mathrm{sec} / \mathrm{m}$ を得 た。

\section{4 重鍾法}

上下動変換器の場合, コイル飞直流電流 $I$ を 流すと同時に振子をもとの位置にもどすべく振子 上の軸から $L_{A}$ の距離の位置に質量 $M_{A}$ の重錘 をのせる。このとき（1）は大部分の項が消えるが 外力のモーメントの項が加わり,

$$
G I+M_{A} g L_{A}=0
$$

ここで,

$g:$ 重力加速度。

振子がもとの位置にもどったことの確認は顕微鏡 で正確に行える。直流電流法とちがって復元力の 非線型項および 動電定数の振子位置によるちがい は，この方法では全く問題にならないという大き な長所があるが，水平動変換器に応用する場合に は摩擦の小さい滑車を用いて 振子を引っぱるよう な細工を工夫する必要がある。この方法を変換器 $A$ にあてはめて得た測定值を図 11 に示す。この 図から電圧感度として $451 \mathrm{~V} \cdot \mathrm{sec} / \mathrm{m}$ を得た。ま た別の変換器 $B$ にあてはめた結果, $124 \mathrm{~V} \cdot \mathrm{sec} / \mathrm{m}$

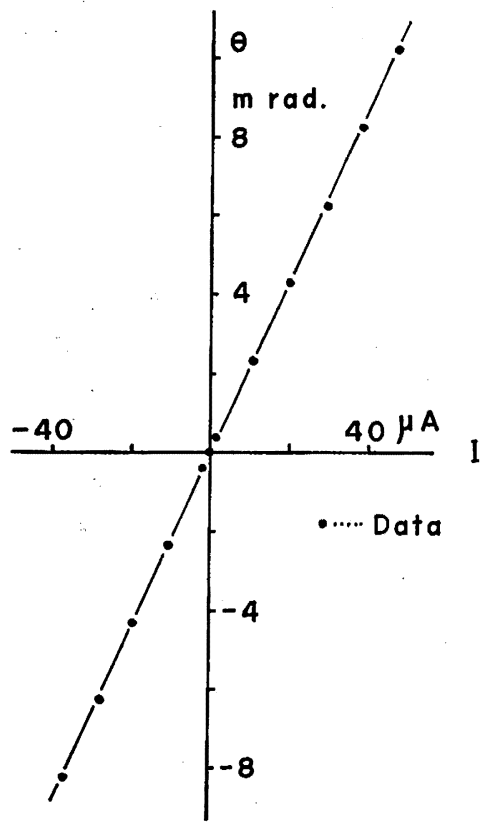

Fig: 10. Relation between the DC current and pendulum angular displacement $\theta$ when the DC current method was applied to transducer $A$.

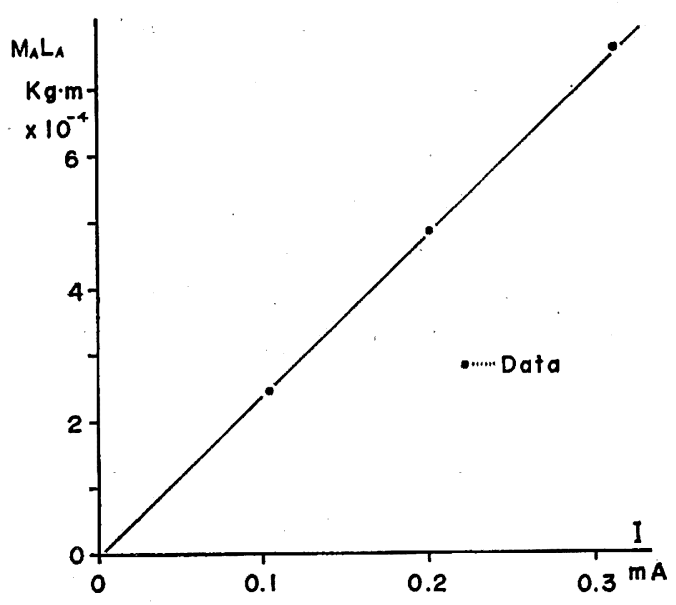

Fig. 11. Relation between the DC current and moment $\mathrm{M}_{\mathrm{A}} \mathrm{L}_{\mathrm{A}}$ when the weight method was applied to transducer $A$.

を得た。

\section{5 交流電流法}

図 12 のようにコイルに交流電流を流すとき（1) は (14) と同様になる。そしてさらに発振器の周 波数が振子の固有振動数より充分大きいときは制 


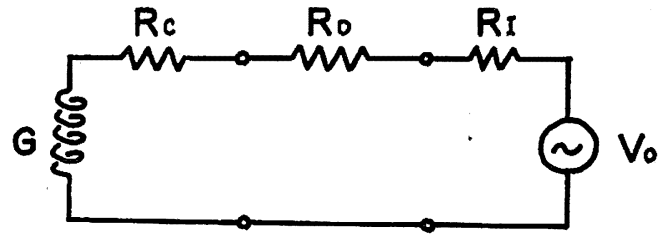

Fig. 12. Circuit diagram of the $A C$ current method.

動力項, 復元力項は慣性力項に比べて充分小さく なり,

$$
K \ddot{\theta}=\frac{G V_{0}}{R_{C}+R_{D}+R_{I}}
$$

$\theta$ は顕微鏡を用いて目の残像を利用して测る。 (35) から動電定数がわかり電圧感度が得られる。 発振周波数が大きくなりすぎるとコイルのインダ クタンスが無視できなくなり（35）に誤差を生じ る。小さい周波数で (35) を成り立たせるために は $R_{D}$ を調節して減衰が最大平坦応答（減衰定数 $h=1 / \sqrt{2}$ ) になるよらにして打㺭ば（35）は固有 振動数の 3 倍の周波数に叔いて $0.6 \%$ の精度で成 り立つ。変換器 $A$ について 3 通りの周波数で実 験した結果， $463 ， 462,448 \mathrm{~V} \cdot \mathrm{sec} / \mathrm{m}$ を得た。

\section{6 テストコイル法}

テストコイルから図 2 のように $V_{0}$ を入力する とき，その周波数が振子の固有振動数より 5.5 に 扣いて述べた意味で充分大きければ（14）は，

$$
K \ddot{\theta}=\frac{G_{2} V_{0}}{R_{C 2}+R_{D 2}+R_{I}}
$$

と近似できる。このときメインコイルの出力 $V_{1}$ は（16）を用いて，

$$
V_{1}=\frac{R_{D 1}}{R_{C 1}+R_{D_{1}}} \cdot \frac{G_{1} G_{2} V_{0}}{\omega K\left(R_{C 2}+R_{D_{2}}+R_{I}\right)}
$$

(37) より $G_{1}$ と $G_{2}$ の積がもとまる。これとは別 に, 振子に任意の振動を与之, 両コイルの出力を 同時に見ることによって $G_{1}$ と $G_{2}$ の比がわかる。 これらによって $G_{1}$ 㧊よび $G_{2}$ が計算でき, 電圧 感度が得られる。変換器 $B$ で実験した結果, 122 $\mathrm{V} \cdot \mathrm{sec} / \mathrm{m}$ を得た。

\section{7 振動台法}

変換器を振動台にのせて振らせ，そのときの振 動台の速度とコイル出力の比から電圧感度を直接 測定する方法である。変換器 $A$ を上下動として 使用して振動台にのせて $450 \mathrm{~V} \cdot \mathrm{sec} / \mathrm{m}$, 水平動と して使用して $480 \mathrm{~V} \cdot \mathrm{sec} / \mathrm{m}$ を得た，振動台が実 際に波形歪なく動いてくれればこの方法は理想的 な方法であろう。しかし振動台の波形は発振器の 波形と比べるとずいぶん悪いのが 通常であるし， また振動台上の位置によっても振幅が異なるとい らこともある。われわれは振動台法では $10 \%$ 程度 の精度を得るのが精一杯であると考えている。し かし感度の基準となる変換器と同時に振らせて, その出力と比較すればまだかなりの 精度の向上が 期待できる。

以上の方法で変換器 $A, B$ について感度を測定 した結果を表 1 にまとめて示す。振動台法の 1 つ のデータ以外はよく一致している。現在まで, 電 圧感度は，ららづけもないまをに測定方法が異な れば結果も異なると考光られているが, 表 10示す ところによれば，振動台法以外の方法で得られた 結果のばらつきは意外に小さい。従って電压感度

\begin{tabular}{|c|c|c|c|c|c|c|c|}
\hline Method & 1 & 2 & 3 & 4 & 5 & 6 & 7 \\
\hline Transducer A & 445 & $\begin{array}{l}453 \\
451 \\
464\end{array}$ & $\begin{array}{l}444 \\
445\end{array}$ & 451 & $\begin{array}{l}463 \\
462 \\
448\end{array}$ & - & $\begin{array}{l}450 \\
480\end{array}$ \\
\hline Transducer B & - & - & - & 124 & - & 122 & - \\
\hline
\end{tabular}

Table 1. Measurement values of the sensitivities of transducers A and B. (unit: $\mathrm{V} \cdot \mathrm{sec} / \mathrm{m}$ )

Method 1: Damping constant method.

2: Condenser method.

3: DC current method.

4: Weight method.

5: AC current method.

6: Test coil method.

7: Vibration table method. 
の測定にあたっては，長さ・質量・周波数・抵抗 值・容量值などを注意深く測定したのちここで 述べた振動台法以外のいずれかの方法で測定すれ ば正確に測ることがでさるといえる。振動台法の 精度が低いのは振動台波形の歪がさけられないか らであろう。

\section{6. むすび}

変換器の正確な検定方法を新しく開発した。こ の検定方法は变換器の初期の特性を測定するため のみでなく，耐振動・衝撃特性，安定性などをた しかめるためにも利用できる。例えば，この方法 で固有振動数を正確に測定すれば直動型变換器の ダイヤフラムバネの不良品が識別できるようにな ったことは一つの成果である。すなわち変換器を 受感方向に傾斜させたとき（これは振子の零位置 を移動させることに相当する) その固有振動数は 多少変化するのは当然だが，その变化が大きなる のほど使用バネが衝撃に対して弱い傾向があると いら経験則が得られた。これは大きな減衰のかか った振子の固有振動数が精度よく測れるようにな ったからこそ実現できたバネのデバッグの一手段 である。

また振動・衝撃ないしは経年によって磁界は微 小な変化をするかしれない。減衰定数・電圧感 度を充分な精度で測定できれば，その変化が検知 できよう。現在までのこれらに対する測定ではあ
まり高い精度が得られていなかったので，この様 な微小変化の経年的な追跡が不可能に近かったが ここに報告した検定法により微小变化の追跡に対 する展望が開けた。このことは地震計測の精密化 といら点で大きな前進があったとい方。

\section{謝辞}

この研究を進めるにあたり有益な助言を頂いた 気象研究所地震火山研究部第二研究室の諸氏に御 礼を申し上げる。特に田教授 (併任, 気象大学校) には発振法という未発表の固有振動数測定法の手 ほどきを受け，その利用価值をここに発表するこ とができた。振動台は東京大学地震研究所のもの を借りて実験を実施し，明石製作所（株，沖電気工 業（株）の振動台を利用してその確めを行った。 これらの協力に謝意をあらわ寸ものである。

\section{参考文献}

Benioff, H., 1960: Long-Period Seismographs. Bull. Seis. Soc. Amer., 50, 7.

田望, 1963: 地震観測用の諸計器の試作. 北海道 大学地球物理学研究報告, 10,143-169.

萩原尊礼，1945：振動測定. 宝文館出版，45-49.

狐崎長琅, 1970: 電磁地震計の理論 (その 3). 物理探 鉱, 23, 37-44.

工藤一嘉・鴁 悦三・佐藤泰夫, 1968 ：臨界制振に近 い状態沉ある地震計の娭定. 地震研究所彙報, 46 , 1313-1324.

\section{地震計電磁変換器の検定方法とその精度について}

松本英照, 高橋道夫

変換器の固有振動数, 減衰定数および電圧感度の従来の検定方法に加えて新しい検定方法を紹介し, それらを用い て実察に検定した結果とその検討を述べる。特䇥すべきことは，新しい方法によると従来はその测定が困難とされた 過減衰の状態にある振子でも固有振動数を容易に $1 \%$ 以下の誤差で測定できることが明らかになった。また臨界減 衰に近い状態にある振子の減衰定数も，固有振動数をそのように正確にもとめた効果で, 従来上り精度よく湘定でき ることを確認した。電圧感度の湘定にはいろいろの方法が用いられたがそれらの結果は，振動台を用いる方法以外は よく一致した。このことは従来から裏付けなしに精度が低いと考兄られている検定法でも充分利用できること，およ び振動台を利用する方法の精度は必ずしも高くないことを意味する。また定数を計算するときに必要々なる機械量と 電気量との間の変換は, 常用単位系である MKSA 単位系を用いることによって桁数の取扱いの煩雑さから解放され ることを併せて強調してある。 